УДК 316.642 .3

О.Г. Цукур

\title{
ОСОБЛИВОСТІ КОМУНІКАТИВНО-ТЕХНОЛОГІЧНОГО ВРЕГУЛЮВАННЯ СОЦАЛЬНИХ КОНФЛІКТІВ У ПРОФЕСІЙНОМУ СЕРЕДОВИЩІ
}

Досліджено особливості комунікативно-технологічного врегулювання соціальних конфліктів у професійному середовищі, де технологія виконує роль унікальної системи обгрунтування вибору засобів, які забезпечують поетапний розвиток компетенцій, необхідних для досягнення мети - взаєморозуміння в професійній групі. Сам комунікативно-технологічний процес врегулювання конфліктів у площині професійних взаємовідносин тлумачиться як послідовність операцій з вибудовування специфічного комунікативного простору шляхом створення спільного контуру розуміння проблемної ситуації для забезпечення ефективної взаємодії між різного рівня групами, що представляють організацію та іiі середовище, та поетапного розв'язання соціальної проблеми, що має організаційну чи соціальну значущість. Обгрунтовується доцільність застосування технології когнітивно орієнтованого спілкування для врегулювання конфліктів у професійному середовищі, яка базується на засадах діалогічності комунікативної взаємодії та рівності представлення інтересів усіх суб'єктів такої взаємодії. Представлено узагальнені результати дослідження особливостей виявлення соціального конфлікту у професійному середовищі: визначено ресурси, що сприяють ефективному врегулюванню соціальних конфліктів у професійному середовищі; вивчено ризики, що утруднюють налагодження конструктивної взаємодії у професійному середовищі, та проаналізовано чинники внутрішнього і зовнішнього середовища організації (соціального інституту), що сприяють реалізації ефективних комунікативних стратегій суб'єктів діалогічної взаємодії.

Ключові слова: комунікативно-технологічне врегулювання соціальних конфліктів, професійне середовище, когнітивний підхід, когнітивне спілкування.

O. H. Tsukur

\section{FEATURES OF COMMUNICATIVE-TECHNOLOGICAL ADJUSTMENT OF SOCIAL CONFLICTS IN PROFESSIONAL ENVIRONMENT}

It is studied the peculiarities of communicative-technological regulation of social conflicts in professional environment, where the technology stands for the unique system of substantiation of means usage that ensure the phased development of the competencies necessary to achieve the goal of mutual understanding in a professional group. Communicative and technological process of conflict management in the area of professional relations is interpreted as a sequence of operations for building a specific communicative space by creating a common contour of understanding the problem situation to ensure effective interaction between different levels of groups representing the organization and its environment, and a phased solution to the social problem that has organizational or social significance. It is substantiated the expediency of cognitive-oriented communication technology usage for resolving conflicts in a 
professional environment based on the principles of dialogicity of communicative interaction and the equality of representation of interests of all subjects of such interaction. There are generalized the results of the study on the features of the identification of social conflict in the professional environment. There are identified the resources which promote the effective regulation of social conflicts in the professional environment. There are analyzed the risks that hinder the establishment of constructive interaction in the professional environment and the factors of the internal and external environment of the organization (social institute) which promote the implementation of effective communicative strategies of the subjects of dialogue interaction.

Key words: communicative-technological regulation of social conflicts, professional environment, cognitive approach, cognitive communication.

Постановка проблеми. Соціальні зміни, що відбуваються в сучасному суспільстві, зумовлюють виникнення нових потреб у багатьох галузях життя, розв’язання яких вимагає переосмислення підходів до врегулювання соціальних суперечностей, що виникають у соціумі. Зокрема, це стосується й організації професійної діяльності як цілісної системи, яка покликана вирішувати соціально значущі завдання, що сприяли б ефективному розвитку країни.

Для професійної сфери визначальними є зрушення, які відбуваються тривалий час у суспільстві і стосуються міжсуб'єктної взаємодії в цілому (структурні зміни окремих соціальних утворень, мотиваційні зміни, зміни в соціальних процесах). Такі соціальні перетворення суттєво впливають на змістову характеристику діяльності окремих професійних груп i, як правило, супроводжуються функціональними соціальними змінами.

Аналізуючи проблемне поле соціальних конфліктів у професійному середовищі, слід означити щонайменше два вектори аналізу. Перший вектор - конфлікти між організаціями та соціумом, що найчастіше загострюються в період глобальних соціальних змін. Другий вектор - це конфлікти в професійному середовищі між різними суб'єктами всередині самої організації. Оскільки будь-яка професійна діяльність пов'язана з вирішенням конкретних соціально значущих завдань, що потребує врахування усіх тих соціальних змін, які постійно відбуваються в суспільстві (соціального контексту), то професійні конфлікти можна розглядати як результат комунікативної взаємодії суб'єкта із зовнішнім комунікативним простором.

Аналіз останніх досліджень і публікацій. На сьогодні більшість досліджень, що так чи так є дотичними до проблематики професійних конфліктів, зосереджені переважно на вивченні окремих аспектів виникнення та подолання суперечностей у професійному середовищі. А це певним чином утруднює цілісне розуміння шляхів їх ефективного врегулювання. Крім того, розширився спектр чинників, які можуть впливати на спрямованість взаємодії суб'єктів у соціальному просторі 
(наявність соціальної напруженості в соціумі між різними групами, стрімкі темпи реформування в деяких галузях, що веде до появи нових соціальних викликів, тощо).

Спроби концептуального осмислення соціальних конфліктів в умовах трансформаційних змін бачимо в науковому доробку вітчизняних та зарубіжних учених, зокрема У. Бека, Д. Бертона, П. Бурдьє, Д. Галтунга, Р. Даля, С. Ліпсета, Н. Лумана, К. Мітчелла, Д. Пруітт, Дж. Рубіна, Л. Саністебан, Е. Тоффлера, С. Хантінгтона. Окремі аспекти, релевантні проблематиці соціальних конфліктів, досліджували В. Татенко (соціальна психологія впливу), П. Фролов (критерії і моделі консолідації суспільства), В. Васютинський (психологія конфлікту мас і спільнот), 3. Сіверс і В. Духневич (когнітивне спілкування в умовах утрудненої взаємодії), Г. Осипов (соціальна структура і соціальні процеси), Н. Луман (суспільство як соціальна система) та ін.

Попри значну увагу науковців до проблеми й досі бракує грунтовного аналізу соціально-психологічних виявів соціальних конфліктів у професійному середовищі та специфіки (особливостей) їх комунікативно-технологічного врегулювання, де останнє можна представити як діяльність, спрямовану на досягнення ефективної міжсуб'єктної комунікації. Ця діяльність полягає у використанні комунікативних процедур і технологій, які забезпечують ефективну взаємодію між різного рівня групами, що представляють організацію та іiі середовище. Соціальна значущість і недостатня розробленість цієї проблеми й зумовили мету нашого дослідження.

Мета статті - обгрунтування доцільності застосування технології когнітивно орієнтованого спілкування для врегулювання конфліктів у професійному середовищі.

Гіпотеза. Специфіка комунікативно-технологічного врегулювання соціальних конфліктів обумовлюється особливостями комунікативного простору професійної взаємодії суб'єктів. Створення спільного контуру розуміння проблемної ситуації в ході когнітивно орієнтованого спілкування підвищуватиме ефективність міжсуб'єктної взаємодії у професійному середовищі.

Виклад основного матеріалу. Технологія являє собою унікальну систему обгрунтування вибору засобів, використання яких забезпечує поетапний розвиток компетенцій, необхідних для досягнення мети взаєморозуміння в професійній групі. У ході розроблення дієвих алгоритмів комунікативно-технологічного врегулювання конфліктної взаємодії враховується наукова обгрунтованість засад модернізації комунікативних сфер суспільства, специфіка створення та використання технологій відповідно до соціальних запитів щодо реалізації актуальних потреб суб'єктів комунікації [1]. Адже суб'єкт комунікації розглядається не лише як носій індивідуального базового знання, а і як ефективний 
партнер по спілкуванню, орієнтований на співпрацю, готовий нести відповідальність та утверджувати цінності соціально-організаційного оточення.

Одним із наукових підходів, що застосовується для конструювання комунікативних технологій врегулювання соціальних конфліктів у професійному середовищі, є когнітивний підхід. Саме когнітивна складова спілкування уможливлює процеси розуміння та взаєморозуміння, зумовлює особливості взаємодії та організації спільної (професійної) діяльності людей. Сам той факт, що професійна діяльність передбачає вирішення досить конкретного соціально значущого завдання, породжує необхідність подолання суперечностей шляхом створення спільного контуру розуміння проблемної ситуації. Досягти цього можна, застосовуючи процедури когнітивно орієнтованого спілкування. Узагальнення наявного досвіду щодо теоретичних засад когнітивної психології спілкування дає змогу задати практичні вектори становлення професійних компетенцій, що зі свого боку сприяє формуванню комунікативного фахового досвіду спеціалістів (зокрема фахівців соціономічних професій).

Від початку 3 60-х років ХХ ст. у психології спостерігається жвавий інтерес до когнітивних досліджень. Прихильники цього підходу (А. Бек і Дж. Келлі, Ж. Піаже та ін.) наголошували на тому, що для ефективного життєздійснення особистості важливо розвивати ії здатність аналізувати інформацію про реальну дійсність, робити порівняння, приймати рішення та розв'язувати різні проблеми, які постають перед нею протягом життя. На думку В. Лук'янець, «розуміння когнітивного як виразу знання, способів представлення та оперування, які стають основою реактивації психічних процесів мислення, покладено в основу відтворення виробництва знання як прояву когнітивної діяльності людини» [2, с. 36]. Саме тому в сучасному науковому дискурсі досить часто когнітивну діяльність людини розглядають як основу когнітивної практики. Наразі саме когнітивна психологія спілкування як напрям соціально-психологічних досліджень вивчає феноменологію і когнітивні процеси, які безпосередньо виявляються у спілкуванні, зумовлюють його перебіг та когнітивне регулювання. Науково-практичні засади соціальних завдань когнітивної психології спілкування пов'язані із забезпеченням спрямованого пошуку конвенціональних умов для спільного осмислення та долання труднощів, психологічних чи соціальних перепон або конфліктів, умов невизначеності або кризи, що унеможливлюють або гальмують творче вирішення завдань соціальнопсихологічного розвитку, громадського узгодження, досягнення суспільної злагоди тощо [3]. В. Казміренко розглядає спілкування як складний, породжуваний потребами спільної діяльності процес налагодження і розвитку контактів між людьми, який передбачає обмін 
інформацією, взаємодію та взаємовплив мотивів і намірів суб'єктів, які спілкуються. Науковець наголошує, що, вступаючи у спілкування, взаємодію, особи завжди мають відповідні потреби та мотиви, реалізують певні наміри [4]. Отже, якщо процес спілкування розгортається 3 метою спільного розв'язання проблеми та супроводжується мисленнєвою активністю суб'єктів або груп, можна говорити про когнітивне спілкування.

Однією зі сфер сучасного життя, де застосування процедур когнітивного спілкування видається найбільш актуальним, є професійна сфера. Аналіз наукової літератури дав змогу виокремити і теоретично обгрунтувати організаційні та соціальні виміри виникнення суперечностей у професійному середовищі. 3 огляду на суспільний контекст було визначено ключові передумови виникнення конфліктів у просторі професійної взаємодії: соціально-політичні зміни, соціально-економічні особливості розвитку країни, реформи у сфері освіти, соціокультурні особливості та соціально-психологічні чинники. Якщо групові інтереси розглядати як єдине і базове джерело соціальних конфліктів, то важливо, власне, дослідити джерела і механізми їх розвитку в контексті сучасних соціальних змін. 3'ясовано, що конфліктна взаємодія у професійному середовищі залежно від його організаційної структури розгортається на двох основних рівнях: горизонтальному (соціальні конфлікти в межах самих соціальних структур) і вертикальному (між структурами, які перебувають у певній ієрархічній взаємозалежності одна щодо одної). При визначенні ресурсної складової дослідників у першу чергу цікавить оцінка сильних і слабких сторін розвитку відповідної професійної галузі в різних умовах; можливості, що при цьому з'являються; небезпеки, що виникають у змінюваних обставинах.

Попередній аналіз результатів дослідження дав змогу визначити ресурси, що сприяють ефективному комунікативно-технологічному врегулюванню сочіальних конфліктів у професійному середовищі:

- сформованість конфліктологічної культури фахівця (уміння налагоджувати контакт на особистісному рівні, враховувати інтереси іншої сторони тощо);

- налаштованість на процес взаємодії (зацікавленість у спільному розв'язанні проблем, активність у ході їх обговорення);

- рівність у значущості позицій, єдність в інтересах і думках (спільне розуміння проблеми).

До чинників, щзо утруднюють врегулювання соиіальних конфліктів у професійному середовищі, можна віднести:

- ігнорування (висловлювання суджень 3 огляду тільки на свої інтереси, думки, ідеї, неувага до думок або почуттів співрозмовника);

- перебивання (зміна теми розмови, зміщення сенсів, переривання співрозмовника); 
- перехід на особистості;

- акцентування на недоліках в кожному реченні без пропонування альтернатив;

- ставлення до своїх позицій як до остаточних і незмінних (позиціонування).

Викладене вище дає змогу пояснити труднощі, які виникають у процесі врегулювання конфліктної взаємодії на різних етапах розгортання (планування, творення спільних смислів, досягнення бажаного результату тощо).

У ході аналізу виявлено зовнішні чинники, щзо сприяють ефективному комунікативно-технологічному врегулюванню сочіальних конфліктів у професійному середовищи:

- упровадження інноваційних технологій у професійну діяльність (використання інтернет-технологій, модернізація структурних одиниць організації);

- відкритість та залучення до громадських обговорень;

- часткова або повна автономність організації, що сприяє творчому розв'язанню конфлікту.

Серед зовнішніх негативних чинників, щз перешкоджають ефективному врегулюванню сочіальних конфліктів у професійному середовищчі, такі:

- непослідовність соціальної політики держави;

- посилення соціальної напруженості в суспільстві на тлі загострення міжрегіональних соціальних конфліктів;

- виникнення нових потреб у багатьох галузях життя, задоволення яких вимагає переосмислення підходів до врегулювання соціальних суперечностей, що виникають у соціумі;

- мотиваційні соціальні зміни, які стосуються передусім трансформації цінностей, норм, ідеалів, цілей.

Отже, можна виокремити дві площини, у яких розгортається конфліктна взаємодія в професійному середовищі, i, відповідно, розглядати 1) соціальний конфлікт, пов'язаний із вирішенням соціально значущих завдань (стосується змісту і цілей роботи) і 2) конфлікт відносин, що зосереджується на міжособових відносинах. Такий розподіл відповідає двом рівням спілкування - змістовому і рівню вибудовування взаємовідносин. Тож, підсумовуючи вищезазначене, можемо констатувати, що комунікативна взаємодія, покликана сприяти результативному вирішенню завдань, характеризується насамперед паритетністю в стосунках і дотриманням певних норм ділової комунікації.

Особливості кожної форми ділової комунікації визначаються певними критеріями:

- мета, відповідно до якої здійснюється ділова комунікація (навіщо); 
- суб'єкти комунікації - учасники, що відстоюють свої інтереси (хто, з ким, для кого);

- процедурність - поетапність вибудовування взаємодії (як довго);

- комунікативні засоби реалізації намірів (як);

- визначення критеріїв спільного розуміння проблеми (яким чином);

- найбільш прийнятний результат (який, що на виході).

Саме за допомогою когнітивного спілкування можна забезпечити послідовне проходження відповідних «сходинок» на шляху до порозуміння у складних особистісно або професійно значущих ситуаціях. У когнітивно орієнтованому спілкуванні ці «сходинки» утворюють своєрідну «драбину», яка передбачає налагодження контакту на особистісному рівні, формування проблемного поля, встановлення інтересів сторін, вирішення завдань для розв'язання проблеми, вихід 3 контакту. Знання про парціальні цілі комунікації частково покладено в основу організації професійних діалогів, про що йдеться в грунтовному дослідженні А. Звєрінцева [5]. Зазначимо, що саме їх вважають одним з найефективніших видів комунікативної діяльності, спрямованим на розв'язання проблем організації співпраці або врегулювання напружених та конфліктних соціальних ситуацій. Саме завдяки організації діалогічності комунікації сторони дістають можливість вибудувати алгоритм спільної діяльності, який і дає зрештою змогу подолати чи усунути суперечності. Іншими словами, професійний діалог - це своєрідне написання сценарію спільної діяльності у вимірах когнітивного спілкування [6]. Основою цієї комунікативної технології є елементи, що формують простір довіри в ході комунікативної взаємодії. Це:

1) налаштованість на партнера по взаємодії. Неприпустимим $є$ перехід на особистості - у фокусі уваги завжди має залишатися проблема, а не особисте ставлення;

2) зосередженість на інтересах, а не на позиціях. Інтереси визначають поведінку людей, опредмечують проблему, дають змогу досягти оптимального рішення, що сприяє узгодженню інтересів сторін. Неуспішність комунікації пов'язана 3 конфліктом позицій, а не $з$ конфліктом інтересів;

3) зацікавленість у пошуку взаємовигідних варіантів подолання суперечностей. Спільна творча діяльність щодо вироблення єдиного розуміння проблеми не тільки підвищує шанси на успішне врегулювання конфліктної ситуації, а ще й сприяє розвитку сталих конструктивних відносин;

4) вироблення об’єктивних критеріїв. Урегулювання конфліктної ситуації буде більш імовірним, якщо всі сторони спиратимуться на спільні критерії щодо оцінки шляхів розв'язання проблеми.

Кожен із розглянутих аспектів має свої соціально-психологічні особливості, нехтування якими може значно знизити ефективність тех- 
нологій когнітивно орієнтованого спілкування у врегулюванні конфліктів у професійному середовищі. Крім того, у межах когнітивної психології спілкування взаємодію окремих соціальних груп можна розглядати як відкриту динамічну систему, в межах якої відбувається постійне обговорення, уточнення та узгодження актуальних суперечностей. А тому, на наш погляд, когнітивний підхід може бути ефективним фундаментом дослідницького процесу, спрямованого на пошуки технологій врегулювання конфліктів у професійному середовищі.

Висновки. У сучасному житті складно знайти галузь професійної діяльності, де б не було актуальним спільне вирішення суперечностей, вироблення нового знання, нових підходів до врегулювання конфліктної взаємодії. Скрізь, де потрібен пошук спільного розуміння та взаєморозуміння, шляхів досягнення консенсусу та домовленостей під час вироблення важливих рішень, ухвалення взаємовигідних проєктів, де ставиться завдання спільними зусиллями досягти оптимального результату, стануть у пригоді процедури когнітивного спілкування. Потреба в ефективному високопрофесійному когнітивному спілкуванні виникає в умовах спільної взаємодії суб'єктів, зусилля яких спрямовані на організацію продуктивної діяльності по вирішенню проблемних питань. Отже, посилюючи когнітивну складову комунікативної сфери, можна забезпечити умови для результативного використання комунікативної технології як засобу врегулювання професійних конфліктів, вирішення актуальних питань взаєморозуміння, розкриття феномену взаєморозуміння професійних груп як проблеми соціально-психологічного аналізу.

\section{Список використаних джерел}

1. Карамушка, Л. М. (Ред.) (2005). Технології роботи організаційних психологів: навчальний посібник. Київ: Інкос. Взято 3 http://www.info-library.com.ua/ books-book-148.html

2. Лук'янець, В. С., Кравченко, О. М., \& Озадовська, Л. В. (2000). Сучасний науковий дискурс: Оновлення методологічної культури. Київ: Генеза.

3. Духневич, В. М. (2014). Прикладні питання технологій підготовки та проведення когнітивно орієнтованих тренінгів спілкування: методичні рекомендації. Київ: Міленіум.

4. Казміренко, В. П. (Ред.) (2013). Засади когнітивної психології спілкування: монографія. Кіровоград: Імекс-ЛТД.

5. Зверинцев, А. Б. (1997). Коммуникаиионный менеджмент: Рабочая книга менеджера PR. Санкт-Петербург: Союз.

6. Кочубейник, О. М. (Ред.) (2018). Соиіальний діалог у вимірах когнітивного спілкування. Кропивницький: Імекс-ЛТД.

\section{References}

1. Karamushka, L. M. (Ed.) (2005). Tekhnolohii roboty orhanizatsiinykh psykholohiv [Technologies of work of organizational psychologists]. Kyiv: Inkos Publ. (ukr). 
2. Lukianets, V. S., Kravchenko, O. M., \& Ozadovska, L. V. (2000). Suchasnyi naukovyi dyskurs: Onovlennia metodolohichnoi kultury [Contemporary scientific discourse: Updating methodological culture]. Kyiv: Heneza Publ. (ukr).

3. Dukhnevych, V. M. (2014). Prykladni pytannia tekhnolohii pidhotovky ta provedennia kohnityvno oriientovanykh treninhiv spilkuvannia: metodychni rekomendatsii [Applied questions of technologies for preparing and conducting cognitive-oriented communication training: methodical recommendations]. Kyiv: Milenium Publ. (ukr).

4. Kazmirenko, V. P. (Ed.) (2013). Zasady kohnityvnoi psykholohii spilkuvannia [Principles of cognitive psychology of communication]. Kirovohrad: ImeksLTD Publ. (ukr).

5. Zverintsev, A. B. (1997). Kommunikatsionnyy menedzhment: Rabochaya kniga menedzhera PR [Communication Management: PR Manager's Workbook]. St. Petersburg: Soiuz Publ. (rus).

6. Kochubeinyk, O. M. (Ed.) (2018). Sotsialnyi dialoh u vymirakh kohnityvnoho spilkuvannia [Social dialogue in the dimensions of cognitive communication]. Kropyvnytskyi: Imeks-LTD Publ. (ukr).

(C) Цукур О. Г. 